\title{
Using community phylogenetics to assess phylogenetic structure in the Fitzcarrald a region of Western Amazonia
}

\section{Correspondence: Jack M. Craig jack.m.craig@gmail.com}

Submitted January 24, 2018

Accepted April 15, 2020

by Brian Sidlauskas

Epub Jun 26, 2020

Online version ISSN 1982-0224

Print version ISSN 1679-6225

Neotrop. Ichthyol.

vol. 18, no. 2, Maringá 2020

\author{
${ }^{\oplus}$ Jack M. Craig ${ }^{1},{ }^{\oplus}$ Tiago P. Carvalho ${ }^{2},{ }^{\oplus}$ Prosanta Chakrabarty 3 , \\ ${ }^{\oplus}$ Valerie Derouen $3,{ }^{\oplus}$ Hernán Ortega $4,{ }^{\oplus}$ Paulo Petry 5 , \\ ${ }^{\oplus}$ Roberto E. Reis ${ }^{6},{ }^{\oplus}$ Victor A. Tagliacollo ${ }^{7}$ and ${ }^{\oplus}$ James S. Albert ${ }^{1}$
}

Here we explore the use of community phylogenetics as a tool to document patterns of biodiversity in the Fitzcarrald region, a remote area in Southwestern Amazonia. For these analyses, we subdivide the region into basin-wide assemblages encompassing the headwaters of four Amazonian tributaries (Urubamba, Yuruá, Purús and Las Piedras basins), and habitat types: river channels, terra firme (nonfloodplain) streams, and floodplain lakes. We present a robust, well-documented collection of fishes from the region including 272 species collected from 132 field sites over 63 field days and four years, comprising the most extensive collection of fishes from this region to date. We conduct a preliminary community phylogenetic analysis based on this collection and recover results largely statistically indistinguishable from the random expectation, with only a few instances of phylogenetic structure. Based on these results, and of those published in other recent biogeographic studies, we conclude that the Fitzcarrald fish species pool accumulated over a period of several million years, plausibly as a result of dispersal from the larger species pool of Greater Amazonia.

Keywords: Biodiversity, Biogeography, Community phylogenetics, Phylogenetic structure.
1Department of Biology, University of Louisiana at Lafayette, 300 E St. Mary Blvd, Lafayette, LA, 70504, USA. (JMC) jack.m.craig@gmail.com (corresponding author); (JSA) jalbert@louisiana.edu.

2 Pontificia Universidad Javeriana, Departamento de Biología, Unidad de Ecología y Sistemática (UNESIS), Carrera 7 N $43-82$, Bogotá D.C., Colombia. pitiago@javeriana.edu.co.

3 Museum of Natural Science \& Department of Biological Sciences, Louisiana State University, 119 Foster Hall, Baton Rouge, Louisiana, 70803, USA. (PC) prosanta@lsu.edu; (VD) vderou1@lsu.edu.

4 Museo de Historia Natural, Universidad Nacional Mayor de San Marcos, Av. Arenales 1256, Jesús María, Lima, Peru. hortega.musm@gmail.com.

5 Museum of Comparative Zoology, Harvard University, 26 Oxford St. Cambridge, MA 02138, USA \& The Nature Conservancy. ppetry@tnc.org.

6 Pontifícia Universidade Católica do Rio Grande do Sul, PUCRS, Av. Ipiranga 6681, 90619-900 Porto Alegre, RS, Brazil. reis@pucrs.br.

7 Museu de Zoologia da Universidade de São Paulo, Av. Nazaré 481, Ipiranga, 04263-000 São Paulo, SP, Brazil. vatagliacollo@gmail.com. 
Aquí exploramos el uso de la filogenética de comunidades como herramienta para documentar patrones de biodiversidad en la región de Fitzcarrald, un área remota en el suroeste de la Amazonía. Para estos análisis subdividimos la región en grupos de toda la cuenca que abarcan las cabeceras de cuatro tributarios del Amazonas (cuencas Urubamba, Yuruá, Purús y Las Piedras) y en los tipos de hábitat: canales fluviales, arroyos de tierra firme (sin planicie aluvial) y lagos de planicie aluvial. Presentamos una colección de peces robusta y bien documentada que incluye 272 especies, colectadas a lo largo de cuatro años y 63 días de campo, en 132 puntos de monitoreo. Convirtiéndose en la colección más extensa de peces de esta región hasta la fecha. Realizamos un análisis filogenético preliminar de la comunidad basado en esta recopilación y recuperamos resultados en gran medida estadísticamente indistinguibles de la expectativa aleatoria, con sólo unos pocos casos de estructura filogenética. Basándonos en estos resultados y los publicados en otros estudios biogeográficos recientes, concluimos que el grupo de especies de peces de Fitzcarrald acumulado durante un período de varios millones de años, se debe posiblemente al resultado de la dispersión del mayor grupo de especies de la Gran Amazonia.

Palabras clave: Biodiversidad, Biogeografía, Estructura filogenética, Filogenética comunitária.

\section{INTRODUCTION}

The global diversity of freshwater fishes is highest in the rivers of the Neotropics, from where 6,080 fish species are currently described (5,607 from South America alone), comprising about $18 \%$ of all known fish species, and about $9 \%$ of all vertebrate species combined (Reis et al., 2016; Van der Sleen, Albert, 2017; Dagosta, de Pinna, 2019). Including as-yet undescribed species, estimates of the total diversity of Neotropical freshwater fishes are in the range of 8,000-9,000 species (Reis et al., 2016). Within the Neotropics, the greatest diversity is concentrated in the Amazon basin, from which more than 2,300 species have been described to date (Albert et al., 2011b; Van der Sleen, Albert, 2017; Oberdorff et al., 2019).

Here we present a study exploring the phylogenetic structure of freshwater assemblages, taking as a representative fauna the Fitzcarrald region of southeastern Peru, a broad $\left(\sim 400,000 \mathrm{~km}^{2}\right)$, low elevation $(200-500 \mathrm{~m})$ structural arch located in southwestern Amazonia (Fig. 1). The Fitzcarrald arch was uplifted in the Pliocene 4 Ma as a result of subduction of the Nazca Ridge (Espurt et al., 2009). This uplift resulted in the partial hydrological separation of four large white-water, Andean tributaries of the Amazon River: the Urubamba $(\mathrm{U})$, Yuruá (Y), and Purús (P) basins, which drain to the western Amazon basin, and the Las Piedras (LP) basin, which drains to the Madeira basin. The aquatic habitats of these basins can be divided into three major categories based on hydrological criteria: small terra firme (non-floodplain) streams, seasonallyinundated floodplains, and large river channels characterized by sand banks and hard clay deposits, with practically no rocky substrates (Albert et al., 2011a; Crampton, 2011). 
Given its mix of habitats, compelling and well-studied geographical history and robust but not overwhelmingly large species pool, the Fitzcarrald region is a promising system in which to explore phylogenetic structure of freshwater assemblages. Furthermore, because the Fitzcarrald region is characterized by many of the same conditions present throughout Neotropical freshwaters, including aspects of geological history such as the Andean uplift, habitat types such as river channels, terra firme streams, and floodplain lakes, as well as many common fish clades such as Ctenobrycon, Hoplias, and Prochilodus, the results of this pilot study are likely to be applicable to other Neotropical faunas.

To explore the phylogenetic structure of assemblages in the river basins and habitats of the Fitzcarrald region, we apply the emerging method of community phylogenetics (Losos, 1996; Webb et al., 2002, 2008; Strauss et al., 2006; Cavender-Bares et al., 2009). Community phylogenetic analyses can estimate two broad types of assemblage structure. First, assemblages in which the constituent species are phylogenetically more distant from one another than expected by chance are considered phylogenetically "overdispersed". Second, assemblages consisting of species more closely related than

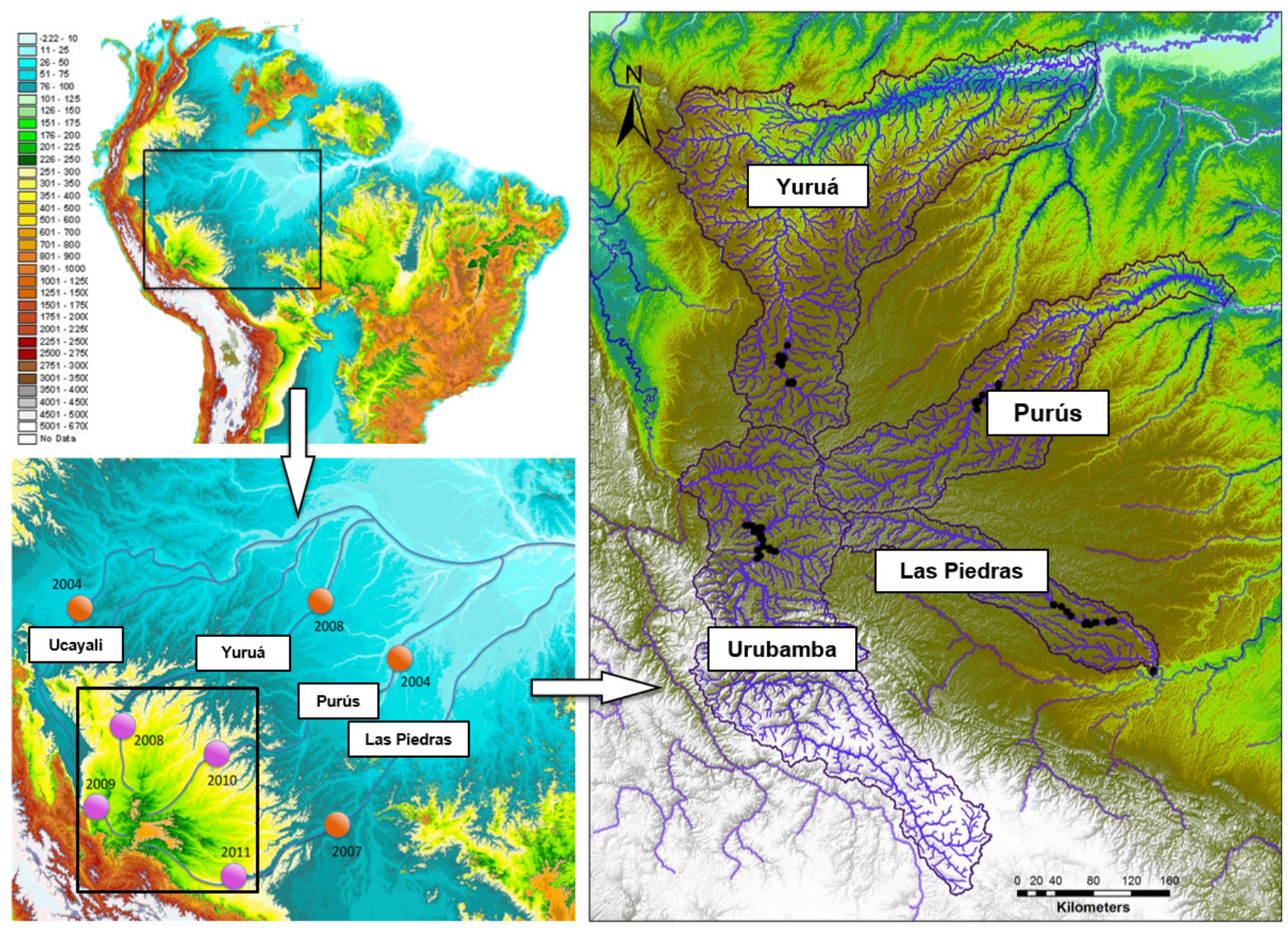

FIGURE 1 I Maps depicting the location and year of collection expeditions in (purple dots) and near (orange dots) the Fitzcarrald region of Southwestern Amazonia. Collections from 77 localities in four river basins (black circles in lower-left image) collected over four field seasons. False-color map images generated from a DEM by Paulo Petry. 
expected by chance are considered phylogenetically "clustered" (Cavender-Bares et al., 2009). These patterns have been used to support several ecological hypotheses. Patterns of overdispersion and clustering may support hypotheses of environmental filtering or competition having influenced local assemblage structure, depending on the spatial and temporal scales (Emerson, Gillespie, 2008). Phylogenetic clustering may indicate phylogenetic conservatism of traits exhibited by species within an assemblage, supporting a hypothesis of habitat filtering during assemblage formation. Phylogenetic clustering may also be consistent with assemblage formation by in-situ speciation. By contrast, phylogenetic overdispersion is consistent with hypotheses of assembly by dispersal or convergent evolution (Cavender-Bares et al., 2009).

The community phylogenetic approach is well suited to testing a number of evolutionary and ecological hypotheses. For example, ecophylogenetic studies can be carried out anywhere from the global scale (Pearse et al., 2019) to the local (Pearse et al., 2013), and can incorporate aspects of clade age based on the underlying phylogeny, adding a temporal dimension not present in some ecological work. Community phylogenetic methods can also be used to infer influences on the formation of a modern assemblage based on the phylogenetic structure of the species therein (Abreu et al., 2019; Zheng et al., 2019). The presence of phylogenetic structure, in the form of either clustering or overdispersion, may suggest non-neutral patterns during assemblage formation. Invasive species are also a topic of several community phylogenetic studies, where communities of low phylogenetic diversity are shown to be less resilient to invasion (Qin et al., 2020), especially from invaders who share few of their traits (Strauss et al., 2006). Invasions of an assemblage may also leave a signature of phylogenetic clustering (Lessard et al., 2009; Barfknecht et al., 2020), making them detectable to community phylogenetic methods.

Most studies using community phylogenetics to date have focused on terrestrial taxa, especially floras (Webb, Peart, 2000; Kembel, Hubbell, 2006; Sargent, Ackerly, 2008; Vamosi et al., 2009; Hawkins et al., 2014; Dexter et al., 2017; Mastrogianni et al., 2019; Zheng et al., 2019), with some work on terrestrial vertebrates (Amador et al., 2019; Caldas et al., 2019; García-Navas, 2019) and reef fishes (Muss et al., 2001). The present work, therefore, serves as a valuable early example of the community phylogenetic approach in Neotropical freshwater fishes. Further, the results of this study and future community phylogenetic work in Neotropical freshwaters holds the potential to better assess the common assumptions that competition, habitat filtering, and habitat conservatism influence assemblage formation, the latter of which has already been subjected to some scrutiny using community phylogenetic methods (Pearse et al., 2014).

\section{MATERIAL AND METHODS}

Collections. We made collections in the upper portions of each of the four major river basins in the Fitzcarrald region: Urubamba (U), Yuruá (Y), Purús (P), and Las Piedras (LP) rivers between 183-328 m elevation during the period of low water (Tab. 1). We collected fishes in three major habitat types: large rivers ( $>40 \mathrm{~m}$ wide) with deep channels ( $>5 \mathrm{~m}$ deep) and flooded beaches, small terra firme (non-floodplain) rainforest streams, and floodplain oxbow lakes (habitats described and quantified in Crampton 
(2011)). We used standard fish collecting equipment at each site including, where appropriate, seine nets (five and $10 \mathrm{~m}$ width with five mm between knots), dip nets, cast nets, gill nets, and hook-and-line. We located electrogenic gymnotiform species using a two-meter length of wire plugged into a RadioShack 9-volt portable audio amplifier via a $3.5 \mathrm{~mm}$ audio jack.

The authors identified all specimens to morphospecies where possible (we queried experienced taxonomists as needed), then photographed vouchers, individually labeled every specimen with a unique field number and preserved them as a reference collection. Catalogued voucher specimens are listed in Carvalho et al. $(2009,2011,2012)$ and Albert et al. (2012). We excised tissue samples from selected vouchers of each species using a sterilized scalpel and stored in $1.8 \mathrm{ml}$ vials of $100 \%$ ethanol in a cool location in the field before being placed in a freezer maintained at $-80^{\circ} \mathrm{C}$ for long-term storage. We then fixed all voucher specimens in $10 \%$ formalin for $>48$ hours in a sealed container at base camp and shipped them to the laboratory with tissue samples. All collected specimens were cataloged at the Museum of Natural History of the University of San Marcos (MUSM), Lima.

In total, 11,162 specimens from 77 field sites were sampled during 63 field days over the course of four project years (2008-2011), with one expedition per year to a different tributary basin. These materials represent 272 valid species in 157 genera, 35 families, and 11 taxonomic orders (S1), or about $9 \%, 28 \%, 56 \%$, and $58 \%$ the total numbers of these ranked taxa among fishes in the whole of Greater Amazonia (totals from Van der Sleen, Albert (2018)). We report only one species as endemic to the Fitzcarrald region: Gymnotus chaviro Maxime, 2009.

Voucher sequences. We generated $16 \mathrm{~S}$ and CO1 voucher sequences for each species present in each river basin when possible, given the limitations of remote field work. We extracted DNA from muscle, fin or liver using the D'Neasy Qiagen extraction kit (Qiagen, Hilden, Germany). For each morphospecies, 2.0 $\mathrm{\mu l}$ of DNA in a total volume of $25 \mu \mathrm{l}$ were amplified by 35 rounds of PCR alternating between 30 s of denaturation at $94^{\circ} \mathrm{C}$, 60s of annealing at $56^{\circ} \mathrm{C}(16 \mathrm{~S})$ or $54-58^{\circ} \mathrm{C}(\mathrm{CO} 1)$ and 80 s of extension at $72^{\circ} \mathrm{C}$, finishing with a final 300 s extension. Temperatures and times varied depending on the gene being amplified. Primers for 16s were 16Sar-L, 16Sbr-H (Palumbi, 1996) and for CO1 were CO1-BOL-F1 5', BOL-R1 5' (Ward et al., 2005). PCR products were then checked on a $1 \%$ agarose gel. PCR products were sequenced at Beckman Coulter Genomics (Danvers, MA). Sequences were visualized in MEGA 7 (Kumar et al., 2016).

TABLE 1 I Summary of the field sites and materials collected across four study years.

\begin{tabular}{|c|c|c|c|c|c|c|}
\hline Basin & Base/ Year & $\begin{array}{c}\text { Latitude } \\
\text { Longitude }\end{array}$ & $\begin{array}{l}\text { Altitude Range } \\
\text { (m) }\end{array}$ & $\begin{array}{c}\text { Field } \\
\text { Stations }\end{array}$ & Field Days & $\begin{array}{l}\text { Museum } \\
\text { Lots }\end{array}$ \\
\hline Yuruá (Y) & $\begin{array}{l}\text { Breu } \\
2008\end{array}$ & $\begin{array}{c}09^{\circ} 31^{\prime} \mathrm{S}, 72^{\circ} \\
45^{\prime} \mathrm{W}\end{array}$ & $232-260$ & 17 & 20 & 880 \\
\hline Urubamba (U) & $\begin{array}{l}\text { Sepahua } \\
2009\end{array}$ & $\begin{array}{c}11^{\circ} 08^{\prime} \mathrm{S}, 73^{\circ} \\
02^{\prime} \mathrm{W}\end{array}$ & $273-310$ & 20 & 16 & 1,255 \\
\hline Purús (P) & $\begin{array}{c}\text { Esperanza } \\
2010\end{array}$ & $\begin{array}{c}09^{\circ} 46^{\prime} \mathrm{S}, 70^{\circ} \\
43^{\prime} \mathrm{W}\end{array}$ & $212-259$ & 17 & 12 & 975 \\
\hline $\begin{array}{l}\text { Las Piedras } \\
\text { (LP) }\end{array}$ & $\begin{array}{l}\text { Pto. Maldonado } \\
2011\end{array}$ & $\begin{array}{c}11^{\circ} 56^{\prime} \mathrm{S}, 70^{\circ} \\
04^{\prime} \mathrm{W}\end{array}$ & $183-328$ & 23 & 15 & 508 \\
\hline Total & 4 years & & $183-328$ & 77 & 63 & 3,618 \\
\hline
\end{tabular}


Phylogeny. Given that mitochondrial markers like the 16S and CO1 collected for this study have difficulty accurately resolving deep phylogenetic nodes (Ortí, Meyer, 1997; Tagliacollo et al., 2016), we estimated rough phylogenetic relationships among fish species of the Fitzcarrald region using a synthetic approach relying on new data and published phylogenetic hypotheses following the methods of Marki et al. (2015) and Kennedy et al. (2017). First, we designated the robust phylogeny reported in Betancur-R. et al. (2013), generated from 20 nuclear genes and one mtDNA gene (16S), as a backbone phylogeny. Second, we manually added species found in the Fitzcarrald region but absent from the backbone as polytomies with their closest present relatives and resolved to the genus level where possible. We used published phylogenies to establish these relationships as follows: Pugedo et al. (2016) and Mirande (2009) for Characiformes, de Pinna (1998) and Sullivan et al. (2006, 2013) for Siluriformes, Albert (2001), Lovejoy et al. (2010) and Tagliacollo et al. (2016) for Gymnotiformes, and Chiachio et al. (2008), Cramer et al. (2011), and Roxo et al. (2014) for Loricariidae. Third, we used the package ape (Paradis, Schliep, 20018) in R (R Core Team 2020) to drop all species tips not present in the Fitzcarrald region from the modified Betancur-R et al. (2013) backbone phylogeny. Thus we generated a synthetic working phylogeny which preserved the branch lengths and deeper relationships of the Betancur-R et al. (2013) backbone where possible (they are valuable in the community phylogenetic approach) and included all 272 fish species from the Fitzcarrald region for which reliable phylogenetic hypotheses could be made. We present the working phylogeny in S2.

To visually demonstrate the phylogenetic distribution of species among basins and habitat types, we displayed presence and absence data at the tips of the working phylogeny. The phylogeny was transformed to an ultrametric cladogram with ordered nodes in FigTree (Rambaut, Drummond, 2018) (Fig. 2).

Community phylogenetics. We explored the phylogenetic structure of each assemblage (four river basins and three habitat types, rivers, lakes, and terra firme streams) using two indices calculated using the picante package in R (Kembel et al., 2010): Mean Phylogenetic Distance (MPD) which estimates the average phylogenetic relatedness between all possible pairs of taxa in a local assemblage and Mean Nearest Taxon Distance (MNTD) which estimates the mean phylogenetic relatedness between each taxon in an assemblage and its nearest relative (Kembel et al., 2010). Thus, the MPD reports structure throughout the phylogeny, while the MNTD focuses on branch tips. The standardized effect size of each metric was calculated using the Net Related Index (NRI) for MPD values and the Nearest Taxon Index (NTI) for MNTD values. To calculate NRI and NTI, we perform a z-Test between the observed phylogenetic distance and the average of 9,999 randomly generated null assemblages, standardized by the standard deviation of phylogenetic distances in the null assemblages (Webb et al., 2002, 2008). In both cases, negative values statistically significantly different from the random expectation indicate a pattern of phylogenetic clustering. By contrast, positive values which are statistically significantly different from the random expectation indicate a pattern of phylogenetic overdispersion. 


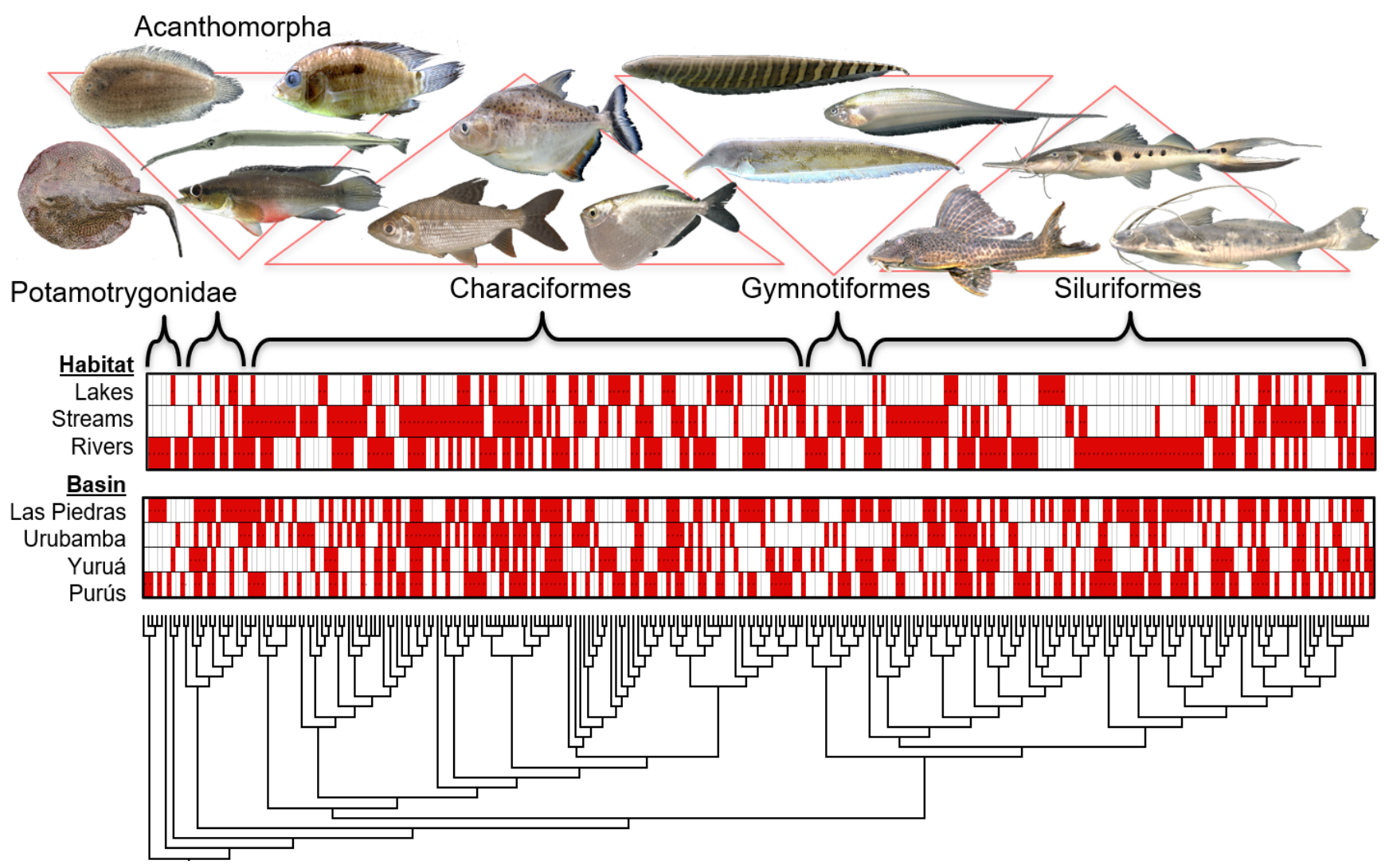

FIGURE 2 I Ultrametric cladogram of the Fitzcarrald region fish fauna (modified from S2) showing distributions of species in habitats and river basins. Red boxes indicate species presences in: Rivers, Stream, Lakes, Purus, Yuruá, Urubamba and Las Piedras. Note phylogenetic clustering in the Urubamba basin and the stream habitat.

\section{RESULTS}

Community phylogenetics. We report no cases of branch-tip phylogenetic structure and only two cases of whole-tree phylogenetic clustering in the assemblages of the Fitzcarrald region, thus the broad patterns reported here were consistent with the random expectation. The stream habitat possesses a statistically significant negative NRI value $(p<0.05)$ and the Urubamba basin possesses a statistically significant negative NRI value $(\mathrm{p}<0.05)$ (Tab. 2).

\section{DISCUSSION}

Scale and novelty. This study is among the largest to date using community phylogenetic methods in fishes, exceeded in scope only by Leprieur et al. (2016), Floeter et al. (2018) and Bower, Winemiller (2019), and among the first applications of these methods to fishes of lowland Amazonia. Our community phylogenetic results suggest that the species present in the assemblages of the Fitzcarrald region were likely drawn from a regional species pool with no new lineages speciating in-situ. This broad pattern has 
TABLE 2 I Species richness (SR), percentage of Fitzcarrald regional fauna, NRI (whole-tree clustering) and NTI (tip-branch clustering) values for the four river basins and three habitat types of the Fitzcarrald region. Asterisks indicate statistical significance $(\mathrm{p}<0.05)$. Note clustering at branch tips for all three habitats and at deep branches for floodplain lake habitats only but none among river basins.

\begin{tabular}{|r|c|c|c|c|}
\hline \multicolumn{1}{|c|}{ Assemblage } & SR & \% Total & NRI & NTI \\
\hline Yuruá (Y) & 113 & 42.01 & -0.57 & -0.82 \\
\hline Urubamba (U) & 108 & 40.15 & $-2.87^{*}$ & -1.21 \\
\hline Purús (P) & 144 & 53.53 & 0.50 & 1.06 \\
\hline Las Piedras (LP) & 140 & 52.04 & 0.05 & -1.09 \\
\hline Rtream (S) & 138 & 56.88 & 0.06 & -0.72 \\
\hline Lake (L) & 72 & 51.30 & $-2.05^{*}$ & -0.96 \\
\hline
\end{tabular}

been reported in several other fish faunas that have been examined by similar methods, including terrestrial (Caley, Schluter, 1997; Westoby, 1998), marine (Belmaker et al., 2008; Harrison, Cornell, 2008) and freshwater (Santorelli et al., 2014; Abreu et al., 2019) systems.

Influences on phylogenetic structure. This study predominantly recovers results statistically indistinguishable from random, revealing a lack of prevalent phylogenetic clustering or overdispersion in the assemblages of the Fitzcarrald region. This suggests a lack of phylogenetic or niche conservatism in the formation of these assemblages, as well as a lack of in-situ speciation or convergent evolution, all of which have been interpreted as driving phylogenetic structure in assemblages (Cavender-Bares et al., 2009; Pearse et al., 2014). Thus, the random nature of these assemblages may support a hypothesis of their formation by effectively neutral dispersal of each species with respect to one another.

In contrast to the broad trend of results which are statistically indistinguishable from random, we recover two instances of phylogenetic structure. First, we recover statistically significant whole-tree phylogenetic clustering (NRI) for species in the stream habitat assemblages (Tab. 2). We propose that this result may reflect a signature of small-bodied taxa specialized to inhabit upland streams (e.g. Stevardiinae, Hemibrycon, Farlowella) dispersing to lowland terra firme streams in the Fitzcarrald region, as is observed in other areas of Amazonia (Mendonça et al., 2005). Second, we recover NRI clustering in the Urubamba basin which may be some evidence of Andean taxa (e.g. Chaetostoma, Parodon pongoense) which are able to disperse to and from and subsequently inhabit this nearby basin, as discussed in Lundberg et al. (1998) and Schaefer (2011) who propose a bi-directional invasion of hill-stream habitats by specialized clades during and following the Andean uplift.

We also propose that any signals of clustering or overdispersion may be harder to recover in the data due to the low resolution among the shallower branches of the phylogeny, which contributes substantial noise to the analysis (Swenson, 2009). 
Limitations of community phylogenetic analysis. Our interpretations of the community phylogenetic results have some important caveats. The lack of a highlyresolved phylogeny, especially among the shallower branches, risks biasing our results toward previously-documented patterns of biodiversity based on deeper relationships where the present phylogeny is better-resolved, or among larger, more fecund, or better-studied species (Hoplias, Prochilodus). Importantly though, Swenson (2009) notes that community phylogenetic analyses are most sensitive to low resolution deeper in the phylogeny, where the present phylogeny is best-resolved. Additionally, the community phylogenetic methods presented here investigate only the present assemblages and do not address any speciation that may have occurred previously, during dispersal, an issue that is compounded by the limitations of the working phylogeny and by present taxonomic knowledge.

Despite the limitations of the present study, there remain several compelling hypotheses within Neotropical ichthyology that might be explored in future community phylogenetic work. For example, the continental assessment of structure based on ecological variables present in Hawkins et al. (2014) could be applied to variables like body size, vagility, and diet in Neotropical fishes to explore patterns of migration and dispersal to complement Araujo-Lima, Goulding (1997) and Barthem, Goulding (1997). Additionally, investigations of invasive species like those of Lessard et al. (2009) and Qin et al. (2020) could be adapted to cases of marine incursion in Neotropical freshwaters (Albert et al., 2006; Bloom, Lovejoy, 2017), or to explore the dynamics of biological corridors like the Casiquiare canal connecting the Orinoco and Negro (Willis et al., 2010), or the Rupununi portal connecting the Branco and Essequibo (de Souza et al., 2012).

Comparison with recent work. Although our community phylogenetic analysis here may not have recovered a strong enough signal of phylogenetic structure to draw powerful conclusions about assemblage formation, our results are more compelling in light of other recent work. Numerous historical biogeographic studies have suggested an important role for assemblage formation by dispersal from regional species pools in the Amazon Basin (Albert, Carvalho, 2011; Albert et al., 2011b; Tagliacollo et al., 2015), and other Neotropical freshwater fish assemblages (Stewart et al., 2002; Arrington et al., 2005; Lujan et al., 2012; 2013; López-Fernández et al., 2013; Picq et al., 2014; Roxo et al., 2014; Roa-Fuentes et al., 2015; Tagliacollo et al., 2015; Thomaz et al., 2015; Melo et al., 2018). While it is not possible to draw macroevolutionary conclusions from community phylogenetics alone (Cavender-Bares et al., 2009; Ewers et al., 2013; Pearse et al., 2014), we do note that robust data on the geological and biogeographic history of the region support an important role for dispersal in assemblage formation, especially in the lowgradient, alluvial (rather than high-gradient, rocky) rivers tested here (Lundberg et al., 1998; Albert, Reis, 2011).

Additionally, such a conclusion would be consistent with a general hypothesized time-frame for the formation of Amazonian fish assemblages during the Neogene c. 22-0 Ma (Lundberg et al., 1998; Albert, Carvalho 2011; Albert, Reis 2011). Based on the time-calibrations present in recent phylogenetic work (Betancur-R. et al., 2013; Tagliacollo et al., 2016; Craig et al., 2019) many lineages would have already given rise to modern species prior to the formation of modern drainages, potentially precluding 
in-situ speciation and supporting assemblage formation by dispersal of modern species. Thus, the present work represents a promising new approach in the increasingly synthetic study of assemblage structure and formation in Neotropical fishes.

\section{ACKNOWLEDGMENTS}

We thank María Aldea, Julio Araujo, Junior Chuctaya, Isabel Corahua, Jessica Espino, Steven Ivanyisky, Fernando Jerep, Emmanuel Maxime, Diana López, Edson Pereira, Blanca Rengifo, Giannina Trevejo, and Roberto Quispe for assistance and comradery in the field, and Jon Armbruster, Maxwell Bernt, William Crampton, Michael Goulding, Damian Green, Lesley Kim, Nathan Lujan, John Lundberg, Hernán López-Fernández, William Pearse, Diogo Provete, Brandon Waltz, Peter van der Sleen, and Kirk Winemiller for discussions and comments on the manuscript. Thanks to A. UrbanoBonilla for proofreading the abstract in Spanish. This work was undertaken with support from United States National Science Foundation awards 0741450 to J.S.A., P.P., and R.E.R, and 1354511 to P.C. and J.S.A. R.E.R. is partially funded by CNPq (process \#306455/2014-5). VAT is supported by FAPESP (process \#2018/20806-3).

\section{REFERENCES}

- Abreu JMS, Craig JM, Albert JS, Piorski NM. Historical biogeography of fishes from coastal basins of Maranhão State, northeastern Brazil. Neotrop Ichthyol. 2019; 17(2):e180156. http://dx.doi. org/10.1590/1982-0224-20180156

- Albert JS. Species diversity and phylogenetic systematics of American knifefishes (Gymnotiformes, Teleostei). Misc Publ Museum Zool Univ Michigan. 2001; 190(190):1-140.

- Albert JS, Carvalho TP. Neogene assembly of modern faunas. In: Albert JS, Reis RE, editors. Historical Biogeography of Neotropical Freshwater Fishes. University of California Press; 2011. p.119-36.

- Albert JS, Carvallo TP, Chuctaya JA, Petry P, Reis RE, Rengifo B et al. Fishes of the Fitzcarrald, Peruvian Amazon. https:// www.lulu.com/en/en/shop/james-albert/ fishes-of-the-fitzcarrald-peruvian-amazon/ paperback/product-1gg8wnzz.html; 2012.

- Albert JS, Carvalho TP, Petry P, Holder MA, Maxime EL, Espino J et al. Aquatic biodiversity in the Amazon: Habitat specialization and geographic isolation promote species richness. Animals. 2011b; 1(2):205-41. https://doi.org/10.3390/ ani1020205
- Albert JS, Lovejoy NR, Crampton WGR. Miocene tectonism and the separation of cis- and trans-Andean river basins: Evidence from Neotropical fishes. J South Am Earth Sci. 2006; 21(1-2):14-27. https:// doi.org/10.1016/j.jsames.2005.07.010

- Albert JS, Petry P, Reis RE. Major biogeographic and phylogenetic patterns. In: Albert JS, Reis RE, editors. Historical Biogeography of Neotropical Freshwater Fishes; 2011a. p.21-57.

- Albert JS, Reis RE. Historical Biogeography of Neotropical Freshwater Fishes. University of California Press; 2011.

- Amador L, Soto-Gamboa M, Guayasamin JM. Integrating alpha, beta, and phylogenetic diversity to understand anuran fauna along environmental gradients of tropical forests in western Ecuador. Ecol Evol. 2019; 9(19):11040-52. https://doi.org/10.1002/ece3.5593

- Araujo-Lima C, Goulding M. So fruitful a fish: ecology, conservation, and aquaculture of the Amazon's tambaqui. Columbia University Press; 1997.

- Arrington DA, Winemiller KO, Layman CA. Community assembly at the patch scale in a species rich tropical river. Oecologia. 2005; 144(1):157-67. https://doi. org/10.1007/s00442-005-0014-7 
- Barfknecht DF, Gibson DJ, Neubig KM. Plant community and phylogenetic shifts in acid seep springs over 49 years following Microstegium vimineum invasion. Plant Ecol. 2020; 221(3):167-75. https://doi.org/10.1007/ s11258-020-01002-7

- Barthem RB, Goulding MJ. The Catfish Connection. Columbia University Press; 1997.

- Belmaker J, Ziv Y, Shashar N, Connolly SR. Regional variation in the hierarchical partitioning of diversity in coral-dwelling fishes. Ecology. 2008; 89(10):2829-40. https://doi.org/10.1890/07-1464.1

- Betancur-R R, Broughton RE, Wiley EO, Carpenter K, López JA, Li C et al. The Tree of Life and a new classification of bony fishes. PLOS Curr. 2013; 5:1-54. https://doi.org/10.1371/currents.tol.53ba26 640df0ccaee75bb165c8c26288

- Bloom DD, Lovejoy NR. On the origins of marine-derived freshwater fishes in South America. J Biogeogr. 2017. 44(9):1927-38. https://doi.org/10.1111/ jbi.12954

- Bower LM, Winemiller KO. Intercontinental trends in functional and phylogenetic structure of stream fish assemblages. Ecol Evol. 2019; 9(24):13862-76. https://doi.org/10.1002/ ece3.5823

- Caldas FLS, Garda AA, Cavalcanti LBQ, Leite-Filho E, Faria RG, Mesquita DO. Spatial and trophic structure of anuran assemblages in environments with different seasonal regimes. Copeia. 2019; 107(3):567-84. https://doi.org/10.1643/CH18-109

- Caley MJ, Schluter D. The relationship between local and regional diversity. Ecology. 1997; 78(1):70-80. https://doi. org/10.1890/0012-9658(1997)078[0070:TRB LAR]2.0.CO;2

- Carvalho TP, Araújo Flores J, Espino J, Trevejo G, Ortega H, Jerep FC et al. Fishes from the Las Piedras River, Madre de Dios basin, Peruvian Amazon. Check List. 2012; 8(5):973-1120. http://dx.doi. org/10.15560/8.5.973

- Carvalho TP, Espino J, Máxime E, Quispe R, Rengifo B, Ortega H et al. Fishes from the lower Urubamba river near Sepahua, Amazon Basin, Peru. Check List. 2011; 7(4):413-42. http://dx.doi. org/10.15560/7.4.413
- Carvalho TP, Tang SJ, Fredieu JI, Quispe R, Corahua I, Orteaga H et al. Fishes from the upper Yuruá river, Amazon basin, Perú. Check List. 2009; 5(3):673-91. http:// dx.doi.org/10.15560/5.3.673

- Cavender-Bares J, Kozak KH, Fine PV, Kembel SW. The merging of community ecology and phylogenetic biology. Ecol Lett. 2009; 12(7):693-715. https://doi. org/10.1111/j.1461-0248.2009.01314.x

- Chiachio MC, Oliveira C, MontoyaBurgos JI. Molecular systematic and historical biogeography of the armored Neotropical catfishes Hypoptopomatinae and Neoplecostominae (Siluriformes: Loricariidae). Mol Phylogenet Evol. 2008; 49(2):606-17. https://doi.org/10.1016/j. ympev.2008.08.013

- Craig JM, Kim LY, Tagliacollo VA, Albert JS. Phylogenetic revision of Gymnotidae (Teleostei : Gymnotiformes), with descriptions of six subgenera. PLoS One. 2019; 14(11)e0224599). https://doi. org/10.1371/journal.pone.0224599

- Cramer CA, Bonatto SL, Reis RE. Molecular phylogeny of the Neoplecostominae and Hypoptopomatinae (Siluriformes: Loricariidae) using multiple genes. Mol Phylogenet Evol. 2011; 59(1):43-52. https://doi.org/10.1016/j. ympev.2011.01.002

- Crampton WGR. An Ecological Perspective on Diversity and Distributions. In: Albert JS, Reis RE, editors. Historical biogeography of Neotropical freshwater fishes. University of California Press; 2011. p.165-89.

- Dagosta FCP, de Pinna M. The Fishes of the Amazon: Distribution and biogeographical patterns, with a comprehensive list of species. Bull Am Mus Nat Hist. 2019; 2019(431):1-163. https://doi. org/10.1206/0003-0090.431.1.1

- Dexter KG, Lavin M, Torke B, Twyford AD, Kursar TA, Coley PD et al. Dispersal assembly of rain forest tree communities across the Amazon basin. PNAS. 2017; 114(10):2645-50. https://doi.org/10.1073/ pnas. 1613655114

- Emerson BC, Gillespie RG. Phylogenetic analysis of community assembly and structure over space and time. Trends Ecol Evol. 2008; 23(11):619-30. https://doi. org/10.1016/j.tree.2008.07.005 
- Espurt N, Baby P, Brusset S, Roddaz M, Hermoza W, Barbarand J. The Nazca Ridge and uplift of the Fitzcarrald Arch: Implications for regional geology in northern South America. In: Hoorn C, Wesselingh FP, editors. Amazonia: Landscape and Species Evolution: A Look into the Past. WileyBlackwell Publishing Ltd.; 2009. p.89-100. https://doi.org/10.1002/9781444306408.ch6

- Ewers RM, Didham RK, Pearse WD, Lefebvre V, Rosa IMD, Carreiras JMB et al. Using landscape history to predict biodiversity patterns in fragmented landscapes. Ecol Lett. 2013; 16(10):1221-33. https://doi.org/10.1111/ele.12160

- Floeter SR, Bender MG, Siqueira AC, Cowman PF. Phylogenetic perspectives on reef fish functional traits. Biol Rev. 2018; 93(1):131-51. https://doi.org/10.1111/ brv.12336

- García-Navas V. Phylogenetic and functional diversity of African muroid rodents at different spatial scales. Org Divers Evol. 2019; 19(4):637-50. https://doi. org/10.1007/s13127-019-00411-5

- Harrison S, Cornell H. Toward a better understanding of the regional causes of local community richness. Ecol Lett. 2008; 11(9):969-79. https://doi.org/10.1111/j.14610248.2008.01210.x

- Hawkins BA, Rueda M, Rangel TF, Field R, Diniz-Filho JAF. Community phylogenetics at the biogeographical scale: Cold tolerance, niche conservatism and the structure of North American forests. J Biogeogr. 2014; 41(1):23-38. https://doi. org/10.1111/jbi.12171

- Kembel SW, Cowan PD, Helmus MR, Cornwell WK, Morlon H, Ackerly DD et al. Picante: $\mathrm{R}$ tools for integrating phylogenies and ecology. Bioinformatics. 2010; 26(11):1463-64. https://doi. org/10.1093/bioinformatics/btq166

- Kembel SW, Hubbell SP. The phylogenetic structure of a neotropical forest tree community. Ecology. 2006; 87(7):S86S99. https://doi.org/10.1890/00129658(2006)87[86:TPSOAN]2.0.CO;2

- Kennedy JD, Borregaard MK, Jønsson KA, Holt B, Fjeldså J, Rahbek C. Does the colonization of new biogeographic regions influence the diversification and accumulation of clade richness among the Corvides (Aves: Passeriformes)? Evolution. 2017; 71(1):38-50. https://doi.org/10.1111/ evo.13080
- Kumar S, Stecher G, Tamura K. MEGA7: Molecular Evolutionary Genetics Analysis Version 7.0 for Bigger Datasets. Mol Biol Evol. 2016; 33(7):1870-74. https://doi. org/10.1093/molbev/msw054

- Leprieur F, Colosio S, Descombes P, Parravicini V, Kulbicki M, Cowman PF et al. Historical and contemporary determinants of global phylogenetic structure in tropical reef fish faunas. Ecography. 2016; 39(9):825-35. https://doi. org/10.1111/ecog.01638

- Lessard JH, Fordyce JAA, Gotelli NIJ, Sanders NJ. Invasive ants alter the phylogenetic structure of ant communities. Ecology. 2009; 90(10):2664-69. https://doi. org/10.1890/09-0503.1

- López-Fernández H, Arbour JH, Winemiller KO, Honeycutt RL. Testing for ancient adaptive radiations in Neotropical cichlid fishes. Evol. 2013; 67(5):1321-37. https://doi.org/10.1111/evo.12038

- Losos JB. Phylogenetic perspectives on community ecology. Ecology. 1996; 77(5):1344-54. http://dx.doi. org/10.2307/2265532

- Lovejoy NR, Lester K, Crampton WGR, Marques FPL, Albert JS. Phylogeny, biogeography, and electric signal evolution of Neotropical knifefishes of the genus Gymnotus (Osteichthyes: Gymnotidae). Mol Phylogenet Evol. 2010; 54(1):278-90. https://doi.org/10.1016/j.ympev.2009.09.017

- Lujan NK, Winemiller KO, Armbruster JW. Trophic diversity in the evolution and community assembly of loricariid catfishes. BMC Evol Biol. 2012;12(1):124. https://doi.org/10.1186/1471-2148-12-124

- Lujan NK, Roach KA, Jacobsen D, Winemiller KO, Vargas VM, Ching VR et al. Aquatic community structure across an Andes-to-Amazon fluvial gradient. J Biogeogr. 2013; 40(9):1715-28. https://doi. org/10.1111/jbi.12131

- Lundberg JG, Marshall LG, Guerrero J, Horton B, Malabarba LR, Wesselingh F. The stage for Neotropical fish diversification a history of tropical South American rivers. In: Malabarba LR, Reis RE, Vari RP, Lucena ZMS, Lucena CAS, editors. Phylogeny and Classification of Neotropical Fishes; 1998. p.13-48. 
- Marki PZ, Fabre-Henri P, Jønsson KA, Rahbek C, Fjeldså J, Kennedy JD. Breeding system evolution influenced the geographic expansion and diversification of the core Corvoidea (Aves: Passeriformes). Evolution. 2015; 69(7):1874-924. https://doi.org/10.1111/ evo.12695

- Mastrogianni A, Kallimanis AS, Chytrý M, Tsiripidis I. Phylogenetic diversity patterns in forests of a putative refugial area in Greece: A community level analysis. For Ecol Manage. 2019; 446:226-37. https://doi.org/10.1016/j. foreco.2019.05.044

- Melo BF, Dorini BF, Foresti F, Oliveira C. Little Divergence Among Mitochondrial Lineages of Prochilodus (Teleostei, Characiformes). Front Genet. 2018; 9:107. https://doi.org/10.3389/ fgene.2018.00107

- Mendonça FP, Magnusson WE, Zuanon J. Relationships between habitat characteristics and fish assemblages in small streams of central Amazonia. Copeia. 2005; 2005(4):751-64. https://doi. org/10.1643/0045-8511(2005)005[0751:RBH CAF]2.0.CO;2

- Mirande JM. Weighted parsimony phylogeny of the family Characidae (Teleostei: Characiformes). Cladistics. 2009; 25(6):574-613. https://doi.org/10.1111/ j.1096-0031.2009.00262.x

- Muss A, Robertson DR, Stepien CA, Wirtz P, Bowen BW. Phylogeography of Ophioblennius: the role of ocean currents and geography in reef fish evolution. Evolution. 2001; 55(3):561-72. https://doi. org/10.1111/j.0014-3820.2001.tb00789.x

- Oberdorff T, Dias MS, Jézéquel C, Albert JS, Arantes CC, Bigorne R et $\boldsymbol{a l}$. Unexpected fish diversity gradients in the Amazon basin. Sci Adv. 2019; 5(9):eaav868. https://doi.org/10.1126/ sciadv.aav8681

- Ortí G, Meyer A. The radiation of characiform fishes and the limits of resolution of mitochondrial ribosomal DNA sequences. Syst Biol. 1997; 46(1):75100. https://doi.org/10.1093/sysbio/46.1.75

- Palumbi SR. Nucleic acids II: The polymerase chain reaction. In: Hills DM, Moritz C, Mable BK, editors. Molecular Systematics. Massachusetts: Sinauer Associates; 1996. p.205-47.
- Paradis E, Schliep K. ape 5.0: an environment for modern phylogenetics and evolutionary analyses in R. Bioinformatics. 20018; 35(3):526-28. https:// doi.org/10.1093/bioinformatics/bty633

- Pearse WD, Jones AF, Purvis A. Barro Colorado Island's phylogenetic assemblage structure across fine spatial scales and among clades of different ages. Ecology. 2013; 94(12):2861-72. https://doi. org/10.1890/12-1676.1

- Pearse WD, Legendre P, Peres-Neto PR, Davies TJ. The interaction of phylogeny and community structure: Linking the community composition and trait evolution of clades. Global Ecol Biogeogr. 2019; 28(10):1499-511. https://doi. org/10.1111/geb.12938

- Pearse WD, Purvis A, Cavender-bares J, Helmus MR. Metrics and models of community phylogenetics. In: Garamszegi LZ, editors. Modern phylogenetic comparative methods and their application in evolutionary biology. Springer-Verlag Berlin; 2014. p.451-64. https://doi. org/10.1007/978-3-662-43550-2_19

- Picq S, Alda F, Krahe R, Bermingham E. Miocene and Pliocene colonization of the Central American Isthmus by the weakly electric fish Brachyhypopomus occidentalis (Hypopomidae, Gymnotiformes). J Biogeogr. 2014; 41(8):1520-32. https://doi. org/10.1111/jbi.12309

- de Pinna MCC. Phylogenetic relationships of Neotropical Siluriformes (Teleostei: Ostariophysi): historical overview and synthesis of hypotheses. In: Malabarba LR, Reis RE, Vari RP, Lucena ZMS, Lucena CAS, editos. Phylogeny and Classification of Neotropical Fishes; 1998. p.279-330.

- Pugedo ML, de Andrade Neto FR, Pessali TC, Birindelli JLO, Carvalho DC. Integrative taxonomy supports new candidate fish species in a poorly studied Neotropical region: the Jequitinhonha River Basin. Genetica. 2016; 144:341-49. https://doi.org/10.1007/s10709-016-9903-4

- Qin TJ, Zhou J, Sun Y, Müller-Schärer H, Luo FL, Dong BC et al. Phylogenetic diversity is a better predictor of wetland community resistance to Alternanthera philoxeroides invasion than species richness. Plant Biol. Published online 2020:00-00. https://doi.org/10.1111/ plb.13101 
- Rambaut A, Drummond A. FigTree: Tree figure drawing tool, v1.4.4. [Internet]. Edinburgh: Institute of Evolutionary Biology, University of Edinburgh; 2018. Available from: http://tree.bio.ed.ac.uk/ software/figtree/

- Reis RE, Albert JS, Di Dario F, Mincarone MM, Petry P, Rocha LA. Fish biodiversity and conservation in South America. J Fish Biol. 2016; 89(1):12-47. https://doi. org/10.1111/jfb.13016

- Roa-Fuentes CA, Casatti L, Romero RM. Phylogenetic signal and major ecological shifts in the ecomorphological structure of stream fish in two river basins in Brazil. Neotrop Ichthyol. 2015; 13(1):165-78. http://dx.doi.org/10.1590/1982-022420140045

- Roxo FF, Albert JS, Silva GSC, Zawadzki CH, Foresti F, Oliveira C. Molecular phylogeny and biogeographic history of the armored neotropical catfish subfamilies Hypoptopomatinae, Neoplecostominae and Otothyrinae (Siluriformes: Loricariidae). PLoS One. 2014; 9(8):e105564. https://doi.org/10.1371/ journal.pone.0105564

- Santorelli S, Magnusson W, Ferreira E, Caramaschi E, Zuanon J, Amadio S. Phylogenetic community structure: Temporal variation in fish assemblage. Ecol Evol. 2014; 4(11):2146-53. https://doi. org/10.1002/ece3.1026

- Sargent RD, Ackerly DD. Plant-pollinator interactions and the assembly of plant communities. Trends Ecol Evol. 2008; 23(3):123-30. https://doi.org/10.1016/j. tree.2007.11.003

- Schaefer SA. The Andes: Riding the Tectonic Uplift. In: Albert JS, Reis RE, editors. Historical Biogeography of Neotropical Freshwater Fishes. University of California Press; 2011. p.259-78.

- de Souza LS, Armbruster JW, Werneke DC. The influence of the Rupununi portal on distribution of freshwater fish in the Rupununi district, Guyana. Cybium. 2012; 36(1):31-43. https://doi.org/10.26028/ cybium/2012-361-004

- Stewart DJ, Ibarra M, Barriga-Salazar R. Comparison of deep-river and adjacent sandy-beach fish assemblages in the Napo river basin, eastern Ecuador. Copeia. 2002; 2002(2):333-43. https://doi. org/10.1643/0045-8511(2002)002[0333:COD RAA]2.0.CO;2
- Strauss SY, Webb CO, Salamin N. Exotic taxa less related to native species are more invasive. PNAS. 2006; 103(15):5841-45. https://doi.org/10.1073/pnas.0508073103

- Sullivan JP, Lundberg JG, Hardman M. A phylogenetic analysis of the major groups of catfishes (Teleostei: Siluriformes) using RAG1 and RAG2 nuclear gene sequences. Mol Phylogenet Evol. 2006; 41(3):636-62. https://doi.org/10.1016/j.ympev.2006.05.044

- Sullivan JP, Muriel-Cunha J, Lundberg JG. Phylogenetic relationships and molecular dating of the major groups of catfishes of the Neotropical superfamily Pimelodoidea (Teleostei, Siluriformes). Proc Acad Nat Sci Philadelphia. 2013; 162(1):89-110. https:// doi.org/10.1635/053.162.0106

- Swenson NG. Phylogenetic resolution and quantifying the phylogenetic diversity and dispersion of communities. PLoS One. 2009; 4(2): e4390. https://doi.org/10.1371/ journal.pone.0004390

- Tagliacollo V, Bernt MJ, Craig JM, Oliviera C, Albert JS. Model-based Total Evidence phylogeny of Neotropical electric knifefishes (Ostariophysi, Gymnotiformes). Mol Phylogenet Evol. 2016; 95:20-33. https://doi.org/10.1016/j.ympev.2015.11.007

- Tagliacollo VA, Roxo FF, Duke-Sylvester SM, Oliveira C, Albert JS. Biogeographical signature of river capture events in Amazonian lowlands. J Biogeogr. 2015; 42(12):2349-62. https://doi.org/10.1111/ jbi.12594

- Team RDC. R: A language and environment for statistical computing. Published online 2020. http://www.rproject.org

- Thomaz AT, Malabarba LR, Bonatto SL, Knowles LL. Testing the effect of palaeodrainages versus habitat stability on genetic divergence in riverine systems: study of a Neotropical fish of the Brazilian coastal Atlantic Forest. J Biogeogr. 2015; 42(12):2389-401. https://doi.org/10.1111/ jbi.12597

- Vamosi SM, Heard SB, Vamosi JC, Webb Co. Emerging patterns in the comparative analysis of phylogenetic community structure. Mol Ecol. 2009; 18(4):572-92. https://doi.org/10.1111/j.1365294X.2008.04001.X

- Van der Sleen P, Albert JS. Field Guide to The Fishes of the Amazon, Orinoco, and Guianas. University of Princeton Press; 2017. https://doi.org/10.1111/faf.12317 
- Ward RD, Zemlak TS, Innes BH, Last PR, Hebert PDN. DNA barcoding Australia's fish species. Philos Trans R Soc B Biol Sci. 2005; 360(1462):1847-57. https://doi. org/10.1098/rstb.2005.1716

- Webb CO, Ackerly DD, Kembel SW. Phylocom: Software for the analysis of phylogenetic community structure and trait evolution. Bioinformatics. 2008; 24(18):2098-100. https://doi.org/10.1093/ bioinformatics/btn358

- Webb CO, Ackerly DD, McPeek MA, Donoghue MJ. Phylogenies and community ecology. Annu Rev Ecol Syst. 2002; 33(1):475-505. https://doi.org/10.1146/ annurev.ecolsys.33.010802.150448

- Webb CO, Peart DR. Habitat associations of trees and seedlings in a Bornean rain forest. J Ecol. 2000; 88(3):464-78. https:// doi.org/10.1046/j.1365-2745.2000.00462.x
- Westoby M. The relationship between local and regional diversity: Comment. Ecology. 1998; 79(5):1825-27. https://doi. org/10.1890/0012-9658(1998)079[1825:TRB LAR]2.0.CO;2

- Willis SC, Nunes M, Montaña CG, Farias IP, Ortí G, Lovejoy NR. The Casiquiare river acts as a corridor between the Amazonas and Orinoco river basins: biogeographic analysis of the genus Cichla. Mol Ecol. 2010; 19(5):1014-30. https://doi. org/10.1111/j.1365-294X.2010.04540.x

- Zheng Y, Dong L, Li Z, Zhang J, Li Z, Miao B et al. Phylogenetic structure and formation mechanism of shrub communities in arid and semiarid areas of the Mongolian Plateau. Ecol Evol. 2019; 9(23):13320-31. https://doi.org/10.1002/ ece3.5787

\section{AUTHOR'S CONTRIBUTION}

Jack McTavish Craig: Conceptualization, Data curation, Formal analysis, Funding acquisition, Investigation, Methodology, Project administration, Resources, Software, Supervision, Validation, Visualization, Writing-original draft, Writing-review \& editing.

Tiago P. Carvalho: Conceptualization, Data curation, Investigation, Validation, Writing-review \& editing. Prosanta Chakrabarty: Conceptualization, Data curation, Investigation, Validation, Writing-review \& editing.

Valerie Derouen: Conceptualization, Data curation, Investigation, Validation, Writing-review \& editing. Hernán Ortega: Conceptualization, Data curation, Investigation, Validation, Writing-review \& editing. Paulo Petry: Conceptualization, Data curation, Investigation, Validation, Writing-review \& editing. Roberto E. Reis: Conceptualization, Data curation, Investigation, Validation, Writing-review \& editing. Victor A. Tagliacollo: Conceptualization, Data curation, Investigation, Validation, Writing-review \& editing.

James S. Albert: Conceptualization, Data curation, Formal analysis, Funding acquisition, Investigation, Methodology, Project administration, Resources, Software, Supervision, Validation, Visualization, Writingoriginal draft, Writing-review \& editing.

\section{ETHICAL STATEMENT}

We collected all specimens and associated field data under annual permits issued by the Peruvian Ministerio de la Producción, Vice Ministerio de Pesquería (MUSM Constancias 28-06-2008, 09-07-2009, 15-06-2010, 19-05-2011). Specimens were also collected with approval from the Institutional Animal Care and Use Committee (IACUC) of the University of Louisiana at Lafayette (protocols \#2007-8717-032, \#2008-8717076, \#2009-8717-070, \#2010-8717-064).

\section{COMPETING INTERESTS}

The authors declare no competing interests. 


\section{Neotropical Ichthyology}

\section{OPEN AcCess}

\section{(c) (i)}

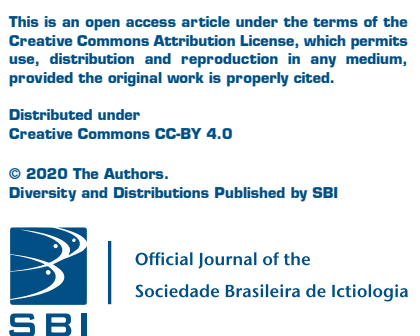

This is an open access article under the terms of the use, distribution and reproduction in any medium,

Distributed under

SBI
HOW TO CITE THIS ARTICLE

- Craig JM, Carvalho TP, Chakrabarty P, Derouen V, Ortega H, Petry P, Reis RE, Tagliacollo VA, Albert S. Using community phylogenetics to assess phylogenetic structure in the Fitzcarrald region of Western Amazonia. Neotrop Ichthyol. 2020; 18(2):e200004. https://doi. org/10.1590/1982-0224-2020-0004 